\title{
The Innovative Platform Programme in South Korea: Economic Policies in Innovation-Driven Growth
}

\author{
Seong Soo Kim \\ Professor, Department of Public Administration, seskim@hufs.ac.kr \\ Yo Sop Choi \\ Associate Professor, Graduate School of International \& Area Studies, yosopchoi@hufs.ac.kr
}

Hankuk University of Foreign Studies, Imun-ro 107, Dongdaemun-gu, Seoul, South Korea, 02450

\begin{abstract}
A fter several decades of rapid development, South Korea has recently experienced a critical economic downturn. The paper considers the prerequisites for the current state-of-the-art, as well as the new economic policy agenda aimed at fostering innovation in various sectors, thereby suggesting improved policy directions. To implement the innovation-driven policy, the Korean
\end{abstract}

Abstract

Keywords: South Korea; Innovative Platform Programme; innovation-driven growth; income-led growth; economic regulation; fair economy; dynamic efficiency; fourth industrial revolution. government produced the framework for the Innovative Platform Programme (IPP), which covers a wide range of sectors related to Industry 4.0 , such as artificial intelligence and blockchain. For the IPP to be successful, the authors believe, it is vital to understand and resolve the trade-offs between contradictory policy priorities - innovation-led growth, income-led growth, and a fair economy.
Citation: Kim S.S., Choi Y.S. (2019) The Innovative Platform Programme in South Korea: Economic Policies in Innovation-Driven Growth. Foresight and STI Governance, vol. 13, no 3, pp. 13-22. DOI: 10.17323/25002597.2019.3.13.22 
$\mathrm{T}$ here is no doubt that South Korea is one of the most successful countries in the world when it comes to industrialization and democratization over a short period of time. In 2018, Korea achieved six hundred billion USD in exports for the first time in history. Korea also became the sixth largest exporter in the world and the seventh biggest economic powerhouse in the '30-50 Club' [Ungson et al., 1997; Bailey et al., 1998; Kim, 2019]. In particular, the well-known candlelight demonstration of the Korean people for the impeachment of ' former President Park in the winter of 2016-2017 and the subsequent peaceful regime change in May 2017 demonstrate the maturity of Korean democracy. Despite recent developments in Korean economy and democracy, the country has faced new challenges. It is notable that the rates of Korean economic growth and employment have recently declined. Consequently, this has prompted demand for new policies for the growth engines that are critical for the Korean economy at present.

In consideration of the issue of economic development, the government of President Moon Jae-In appears to move towards more 'innovation-driven growth' in an effort to provide an impetus for economic growth and the move towards the fourth industrial revolution. Accordingly, the Korean government announced a new policy for the innovation initiative in 2018, the socalled Innovative Platform Program (hereinafter the IPP). Under the IPP, the Korean government seeks to improve the platform economy, which is a comprehensive ecosystem and infrastructure for future industries [Korean Government, 2018]. This explains the Korean government's goal of a gradual shift towards becoming a global center for information and communications technology (ICT) in the era of digitalization ${ }^{1}$. This policy is part of an all-inclusive plan to create new growth drivers.
In particular, recent economic policy on unemployment and income polarization has brought serious discussions on the role of the IPP, with an emphasis upon job creation and deregulation relating to science and technology. To solve these existing problems, the IPP focuses on the three major areas of strategic investment: a data economy, artificial intelligence (AI), and a hydrogen economy. In addition to these three areas, the government further emphasized the importance of raising innovative human resources [Korean Government, 2018]. The overall framework of the IPP is shown in Table 1.

The purpose of this article is to explore recent Korean economic policies on innovation-driven growth, together with income-led growth, as will be further discussed below, thereby to suggest proposals for future policy on the new digitalization economy.

\section{The Challenges of the Korean Economy from a Historical Perspective}

Since the Second World War and Korean War, Korea has shown its ability to overcome various obstacles to development, such as the division of the country, poverty, and dictatorship. Most of all, economic and political recovery lies at the heart of the government's policy. Eventually, Korea made a notable economic leap from one of the poorest countries to becoming a high-income industrial democracy through the socalled Miracle on the Han River. During the 1960s and 1970s, the Korean government introduced exportoriented policies to overcome intrinsic limitations in the small market economy. Its policy focused on the support of heavy and chemical industries. However, its approach generated economic concentration in large conglomerates, the so-called chaebols of family-owned business groups. In other words, its designation of na-

\section{Figure 1. The Growth Rate and Job Creation}

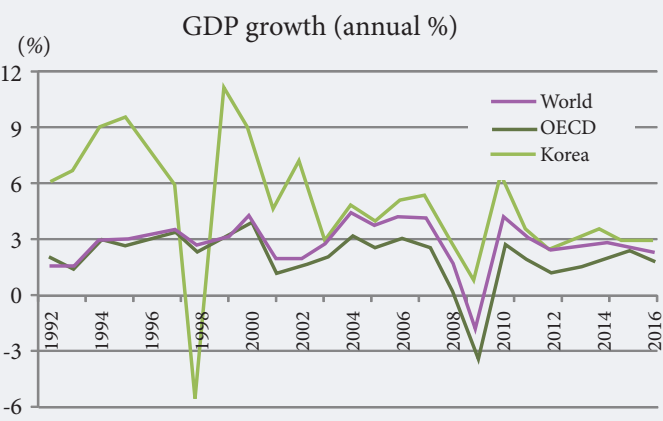

Unit: Thousand people, Year-over-year

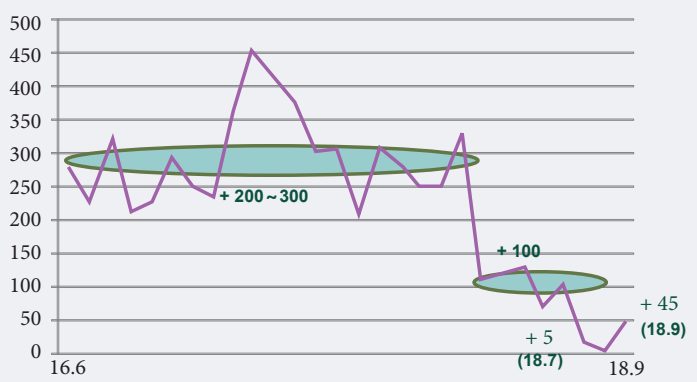

Sources: [OECD, 2017; Statistics Korea, 2019].

Among the key elements of the digital economy, different authors highlight, for example, search engines, social network services, software, computers, communications, pharmaceuticals, and so on. [Posner, 2001; Viscusi et al., 2018]. 


\section{Table 1. The Framework of the Korean Government's IPP}

\begin{tabular}{|c|c|}
\hline Dimensions & Contents \\
\hline $\begin{array}{l}\text { Four Policy } \\
\text { Directions }\end{array}$ & $\begin{array}{l}\text { - Innovation of the Social System } \\
\text { - Innovation of Science \& Technology } \\
\text { - Innovation of Human Resources } \\
\text { - Innovation of Industries }\end{array}$ \\
\hline $\begin{array}{l}\text { Three Strategic } \\
\text { Investment Areas }\end{array}$ & $\begin{array}{l}\text { - Data Economy (Block Chain \& Sharing } \\
\text { Economy) } \\
\text { - Artificial Intelligence } \\
\text { - Hydrogen Economy }\end{array}$ \\
\hline $\begin{array}{l}\text { Eight Leading } \\
\text { Industries }\end{array}$ & $\begin{array}{l}\text { - Smart Factory } \\
\text { - Smart Farm } \\
\text { - Smart City } \\
\text { - Future Vehicle } \\
\text { - Fintech } \\
\text { - New Energy } \\
\text { - Bio-Health } \\
\text { - Drone }\end{array}$ \\
\hline
\end{tabular}

tional-champion companies brought various problems [Eichengreen, Chung, 2004]. For example, the market power of large firms created anti-competitive or unfair business practices from unequal bargaining powers. This brought about a call for economic reform that was based on the concept of a social market economy and economic democratization [Kim S.S., 2017]. This idea focused on the protection of individual economic freedom from the abuse of large conglomerates and has influenced overall government policies on the market economy in Korea since the 1990s [Choi, 2014].

Korea has faced new challenges over the past decade: the decrease of its economic growth rate and employment rate has been significant (Figure 1). This means that the traditional growth model, which relied upon big businesses and export-led approaches, has reached its limits, and a new growth model has to be created. Moreover, policies based on the 'trickle-down effect' were proven unsuccessful in the period of the con- servative governments of two former Presidents, Lee Myung-Bak and Park Geun-Hye. While the trickledown effect tends to recall chaebol-friendly policies in that the growth of the rich could improve that of the poor [Aghion, Bolton, 1997], the boom of exports and big businesses has not led to an increase in middle class income. In this context, the new Moon government adopted new economic policies that mainly focus on the income growth of the middle class and brought the emergence of political goals for economic democratization which widely regulates large conglomerates through stringent amendments to the Korean competition act, the Monopoly Regulation and Fair Trade Act (hereinafter the MRFTA). Moreover, it was ultimately necessary for the government to change the direction of economic policy to be more effective in the actual distribution of wealth. As a result, the Korean government started considering the creation of a new growth model.

\section{New Economic Strategy}

The current government's policy pursues economic democratization while emphasizing the importance of an effective balance between innovation-led economic growth, rising incomes, and social welfare in many cases based on fair competition ${ }^{2}$. The concept of innovative growth involved the creation of new growth engines for the Korean economy. Income-driven development would be critical for sustainable economic growth and income- and innovative-driven growth would be possible where a fair economy and fair competition was ensured.

Among others, the governmental strategy of incomeled growth is composed of three main policies: (i) increasing the household incomes of both regular employees and the self-employed, (ii) the reduction of living costs to improve actual income level, and (iii)

\section{Table 2. Three Policies for Economic Growth}

\begin{tabular}{|c|c|}
\hline Policy Direction & Contents \\
\hline $\begin{array}{l}\text { The Policy for } \\
\text { Income-led Growth }\end{array}$ & $\begin{array}{l}\text { - Improvement of household income } \\
\text { - Reduction in living costs } \\
\text { childcare, basic pension, etc.) }\end{array}$ \\
\hline $\begin{array}{l}\text { The Policy for } \\
\text { Innovation-driven } \\
\text { Growth }\end{array}$ & $\begin{array}{l}\text { - Deregulation, including regulatory sandbox projects } \\
\text { - Fostering new entrepreneurship, including the commercialization of new technologies } \\
\text { - Thengthening major industry sectors } \\
\text { - The promotion of the fourth industrial revolution }\end{array}$ \\
\hline $\begin{array}{l}\text { The Policy for } \\
\text { Fair Economy or } \\
\text { Competition }\end{array}$ & $\begin{array}{l}\text { - Improvement of corporate governance with the aim of greater transparency and accountability } \\
\text { - Establishment of fair market order (or fair competition), such as the protection of franchisees, small } \\
\text { businesses, and weaker parties in subcontracting agreements } \\
\text { - Effective cooperation between large and small businesses with regards to the protection of innovative ideas or } \\
\text { products of spin-offs } \\
\text { - Protection of consumer interests }\end{array}$ \\
\hline
\end{tabular}

Speech of the President at the Ministerial Meeting (28 August 2018) is available online at: https://www1.president.go.kr/articles/4094, accessed 30.05.2019 (in Korean). 


\section{Figure 2. The Structure of Income-Led Growth Policy}

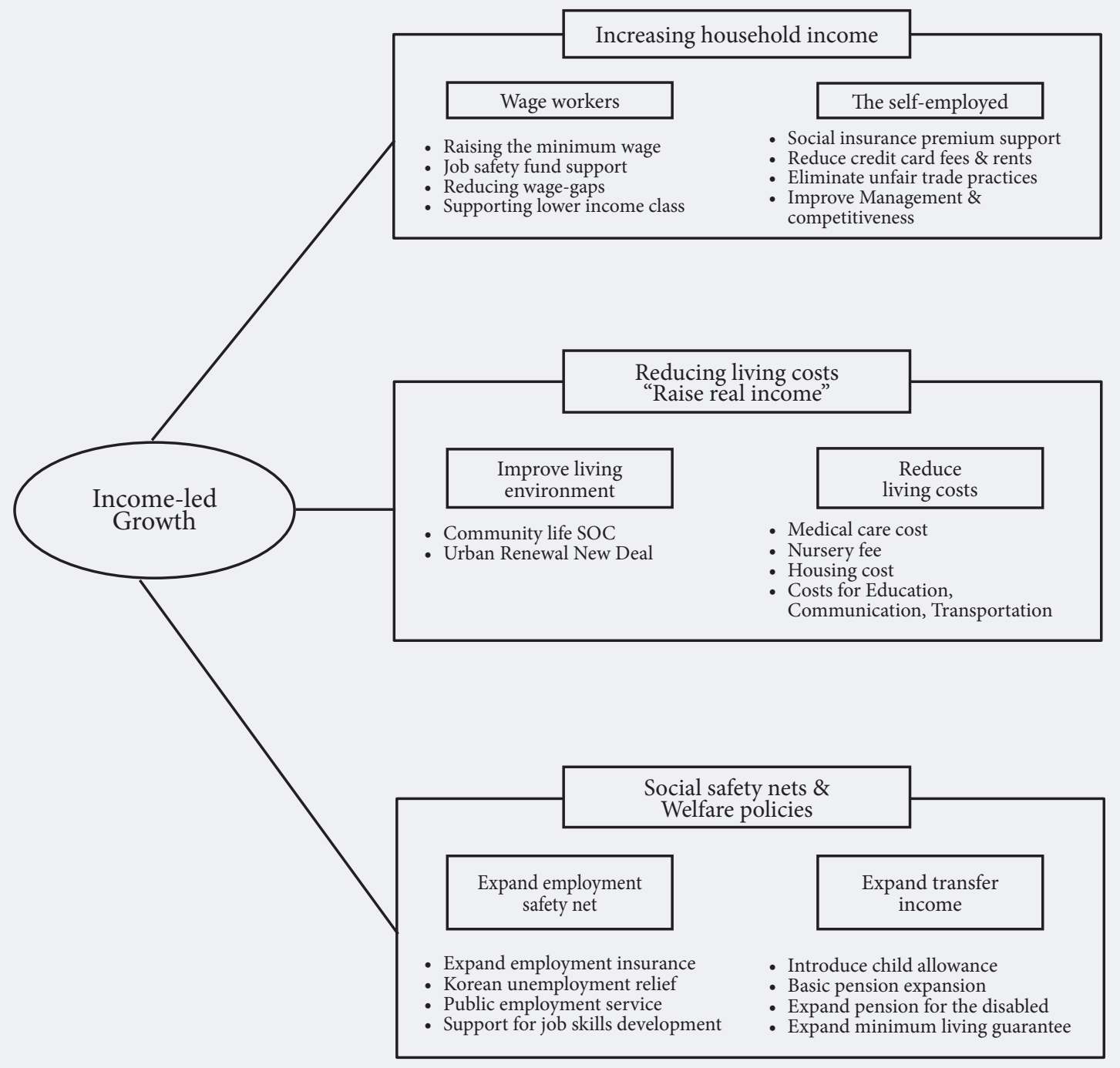

Source: [Presidential Committee, 2019].

\section{Figure 3. Statistics of Employment and Income Distribution in 2018}

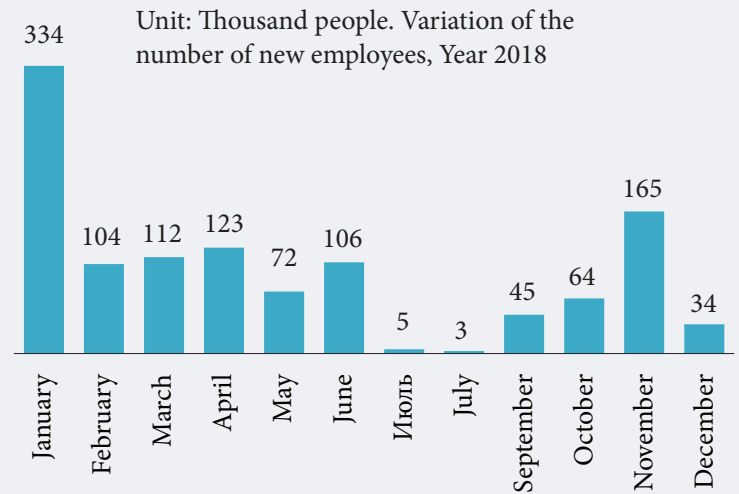

Sources: [Statistics Korea, 2018, 2019a, 2019b, 2019c].
Unit: $100 \%$. Disposal income quintile ratio (highest income quintile / lowest income quintile), as of the third quartier of every year

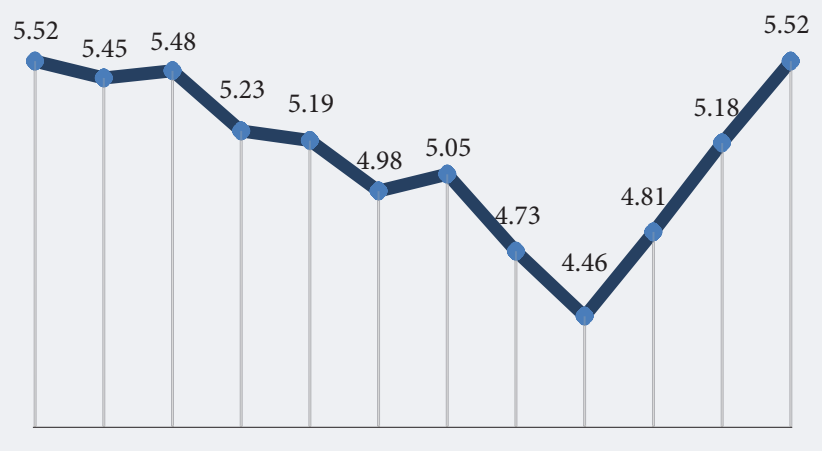

200720082009201020112012201320142015201620172018

Note: The graph on the right indicates the relative distribution of disposal income for the top $20 \%$ and bottom $20 \%$ households; the larger number means more inequality. Disposal income is the sum of employee income, self-employment income, property income and transfer income with a minus of public transfer expenditure, such as a regular tax, etc. 
Table 3. The Growth Engine Programs in Korea

\begin{tabular}{|c|c|c|c|c|c|}
\hline $\begin{array}{c}\text { Implementation } \\
\text { Period }\end{array}$ & G7 Project & $\begin{array}{c}\text { Next Generation } \\
\text { Growth Engine }\end{array}$ & New Growth Engine & $\begin{array}{c}\text { Future Growth } \\
\text { Engine }\end{array}$ & $\begin{array}{c}\text { Innovation Growth } \\
\text { Engine }\end{array}$ \\
\cline { 2 - 6 } Keywords & $1992-2002$ & 2003 & 2009 & 2014 & 2017 \\
\hline Leading Countries & $\begin{array}{c}\text { Securing Technology } \\
\text { Competence of Major } \\
\text { Industries }\end{array}$ & $\begin{array}{c}\text { Green Growth, } \\
\text { Fostering Service } \\
\text { Industries }\end{array}$ & $\begin{array}{c}\text { Convergence of } \\
\text { S\&T and ICT }\end{array}$ & $\begin{array}{c}\text { S\&T, ICT, } \\
\text { the 4th Industrial } \\
\text { Revolution }\end{array}$ \\
\hline $\begin{array}{c}\text { Number of Target } \\
\text { Industries }\end{array}$ & 18 & 10 & 17 & 19 & 13 \\
\hline $\begin{array}{c}\text { Responsible } \\
\text { Ministry }\end{array}$ & Ministry of S\&T & Ministry of S\&T & Ministry of Industry & $\begin{array}{c}\text { Ministry of } \\
\text { Education and S\&T }\end{array}$ & $\begin{array}{c}\text { Ministry of Science } \\
\text { and ICT }\end{array}$ \\
\hline \multicolumn{2}{|l}{ Source: compiled by the authors based on [MSICT, 2018]. }
\end{tabular}

the expansion of social security nets and the scope of welfare policies (Figure 2).

The income-led policy has been a controversial issue in the recent government's economic policy. One of the critical questions about this policy is whether the minimum wage, set by the government, can improve economic growth and create jobs on the labor market. In effect, this subject has been hotly debated in Korea. There are some dissenting views about the actual effects of economic growth by income-led policy [Park, 2019]. Interestingly, the assessments of income-led policy depend upon political views because the opinions of progressive parties are different from those of conservative ones. Most of all, as the empirical economic statistics on unemployment and income distribution deteriorated in the summer of 2018, the debate on the effects of income-led growth intensified. Accordingly, an argument for innovation-led growth emerged as an alternative way to achieve economic development.

At the time of writing, it is not certain whether increasing the minimum wage was the key reason for the deterioration of employment. Commentators, who favor increasing the minimum wage, appear to explain that the existing difficulties of small businesses stem from the depression in major manufacturing industries, including automobiles and shipbuilding, and the rapid changes in consumers' behavior. On the contrary, opposing critics assert that there is an intrinsic problem within the policy on the minimum wage increase and income-led growth itself. They called for an innovation-led growth policy to revitalize the economy for the benefit of the public [Kim G.H., 2017; Lee, 2018; Kim, 2018]. This argument formed the background of the innovation-led policy of the current government.

\section{The Innovation-led Growth Policy of Korea}

\section{A Brief History of the Growth Engine Programs in Korea}

Since the 1990s, the Korean government has implemented overall policies on growth engine programs
(Table 3). Starting with the G7 project (1992-2002), the government carried out numerous programs, including the next generation growth engine (2003), the new growth engine (2009), the future growth engine (2014), and the innovative growth engine (2017). The main goals of each growth engine program can be categorized into three topics: (i) the advancement of major industries, (ii) the increase of global market shares, and (iii) the support of new industrial sectors. These programs have strengthened Korea's position on the global market. It became a leading country in major manufacturing industries, including automobiles, telecommunications, and semiconductors. Moreover, Korean companies in the fields of high-speed railways, rechargeable batteries, and robot industries have acquired important technologies and improved their shares on the global market. In recent years, the new economic sectors involving the fourth industrial revolution have been included in the Korean growth engine program.

The innovation growth engine program, which has been implemented by the current government, targets numerous sectors: big data, next generation communications, AI, autonomous driving vehicles, drone, smart city, virtual reality, personalized healthcare, intelligent robot, innovative new drugs, new and renewable energy, intelligent semiconductors, and advanced materi$\mathrm{als}^{3}$. In effect, the government's IPP was the outcome of a discussion regarding the 13 aforementioned sectors, which served as the foundations for four policy directions, three strategic investment areas, and eight leading businesses ${ }^{4}$.

\section{The Main Tasks of the Innovative Platform Program (IPP)}

The focus of the program is on progress concerning infrastructure, technologies, and ecosystems that are essential in numerous industrial sectors, such as big data and algorithms. It is beyond doubt that the platform economy has become vital in Korea, especially in the era of the fourth industrial revolution. Nonetheless, it

\footnotetext{
This program was created in December 2017 at the National Science and Technology Advisory Council, a private advisory body.

${ }^{4}$ Approved at the fifth innovative growth ministerial meeting in August 2018 [Ministry of Economy \& Finance, 2018]
} 


\section{Figure 4. The Main Structure of the IPP}

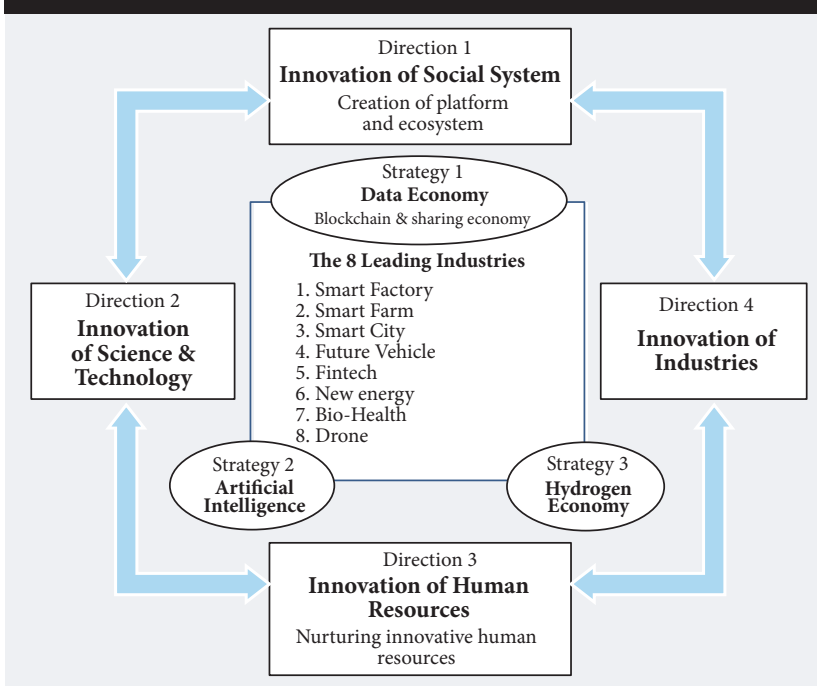

Source: [Korean Government, 2018].

is difficult for Korean enterprises to invest in platforms due to the large financial investments necessary along with the associated risk of failure. Therefore, it appears that governmental strategic investment is necessary for the development of IPP-related industries. As a result of a series of ministerial meetings, the government's 2018 announcement contains its financial investments relating to big data, AI, blockchain, sharing economies, and hydrogen economies.

The four policy directions that comprise IPP are presented in Table 4

\section{The Three Strategic Investment Areas}

Under the IPP scheme, the government also provides three major strategies for investment areas: (i) big data, blockchain, and sharing economies, (ii) AI, and (iii) hydrogen economies. These are commonly reinforced by supporting innovative human resources in prom- ising future technologies. The three fields of strategic investment are selected for a number of reasons: (i) the possibility of leaping forwards as a leading country through providing investment and (ii) the establishment of platforms and infrastructure that innovate economic structures and industrial ecosystems, create jobs, and contribute to the quality of living [Korean Government, 2018].

Firstly, with regards to the data economy, the Korean government focuses on areas relating to big data, blockchain, and a sharing economy. The government seems to include various fields for the data economy, such as big data platforms, big data networks, data vouchers, and public Wi-Fi. Most of all, the big data networks can be established by activating data opening and trading in major fields, such as transportation, energy, environment, communications, and finance. With regards to data transactions, the government is preparing to design standards for transaction and quality control. To build a big data network, the government is also willing to revise the relevant regulations in 2019, including those concerning data protection and privacy. In addition, this project includes the area of blockchain, which is concerned with experimental projects and advanced technology for securing data and reliable data transactions.

Secondly, the area of $A I$ is also the basis for big data, blockchain, and sharing economies. It is a founding technology for the creation of high value-added industries by linking other sectors. The key technologies are Quantum computers, AI-involved algorithms, and intelligent semiconductors, among others. In effect, big data and AI are closely related. As a result, the government aims to develop the big data market by investing 30 trillion KRW by 2023. In particular, the government is willing to educate 10,000 experts in the areas of big data and AI. Its mid-term plan includes launching one hundred big data centers and ten big data platforms, the promotion of data production and its utilization, and the establishment of AI hubs [Ministry of Economy \& Finance, 2019a].

\section{Table 4. The Four IPP Policy Directions}

\begin{tabular}{|c|c|}
\hline Innovation Fields & Tasks \\
\hline $\begin{array}{l}\text { Social System and } \\
\text { Institutions }\end{array}$ & $\begin{array}{l}\text { - revise regulations } \\
\text { - improve fairness on the market } \\
\text { - establish a framework to promote innovative start-ups by advancing a culture of entrepreneurship }\end{array}$ \\
\hline Science and Technology & $\begin{array}{l}\text { - hi-tech improvement } \\
\text { - create infrastructure for the fourth industrial revolution } \\
\text { facilitate an environment for creative research } \\
\text { - enhance efficiencies, promote research on science and technology } \\
\text { - adopt international standards }\end{array}$ \\
\hline $\begin{array}{l}\text { Human Resources } \\
\text { [Ministry of Economy \& } \\
\text { Finance, 2019b] }\end{array}$ & $\begin{array}{l}\text { - design a new policy for education and training programs to nurture creative human resources. } \\
\text { - establish three graduate schools for AI research to train world-class experts (the plan is to educate 40,000 } \\
\text { AI engineering specialists by 2022) }\end{array}$ \\
\hline $\begin{array}{l}\text { Innovative Industries } \\
\text { [Korean Government, } \\
\text { 2019] }\end{array}$ & $\begin{array}{l}\text { - create an ecosystem to accelerate venture enterprises } \\
\text { - develop service sectors and emerging industries } \\
\text { - strengthen major industries } \\
\text { promote corporate innovation }\end{array}$ \\
\hline
\end{tabular}


Table 5. The Investment Plan for Three Strategic Areas and Human Resources (billion KRW)

\begin{tabular}{|c|c|c|c|c|}
\hline \multirow{2}{*}{ Programs } & \multirow{2}{*}{2018 (A) } & \multirow{2}{*}{2019 (B) } & \multicolumn{2}{|c|}{ Increase } \\
\hline & & & (B-A) & $\%$ \\
\hline Total & 870.0 & 1490.0 & 620.0 & 71 \\
\hline Data, AI, Block Chain, Sharing Economy & 579.9 & 1040.0 & 460.0 & 79 \\
\hline Building infrastructure for big data, AI and block chain & 39.7 & 190.0 & 150.0 & 378 \\
\hline Resolving the data divide, sharing economy package & 6.8 & 130.0 & 120.0 & 1765 \\
\hline Hydrogen Economy & 42.2 & 110.0 & 70.0 & 166 \\
\hline Testing R\&D and constructing production bases & 37.2 & 100.0 & 60.0 & 161 \\
\hline Human Resource Development & 247.9 & 340.0 & 90.0 & 36 \\
\hline Training and developing 10,000 talented personnel, introducing educational program & 24.0 & 90.0 & 70.0 & 292 \\
\hline
\end{tabular}

Thirdly, the project for hydrogen economies is an important platform for the new energy paradigm shift, energy security, and future industries. The hydrogen economy policy deals with programs for hydrogen production and storage for transportation, usage, and safety purposes. The government has also attempted to expand the demand base for hydrogen energy. This plan includes its aim to increase hydrogen fuel cell cars from 2,000 in 2018 to approximately 80,000 in 2022. Its purpose includes an ecosystem for the mutual growth of large and small enterprises, the development of high-quality human resources, and the achievement of international standards [Ministry of Economy \& Finance, 2019a].

The plans for investing in the considered directions are presented in Table 5.

\section{The Eight Major Leading Industries}

The 2019 governmental project also listed the eight leading industries associated with the IPP: smart factory, smart farm, fintech, new energy, smart city, drone, future vehicle, and bio-health [Korean Government, 2019]. The first leading industries sector is the smart factories field. The government plans to increase its investment amount, thereby establishing 4,000 smart factories in 2019, and has further announced its focus on $5 \mathrm{G}$ technology for improving smart factories by developing and smart-manufacturing hardware and software technology packages. The second sector involves the field of bio-health. The government aims to provide a development strategy for the midand long-term perspectives, which includes creating various new medical services by offering a regulatory sandbox relating to gene inspection and wearable electrocardiograms. It has also tried to establish a 'healthcare big-data showcase' for providing and managing big healthcare data. The overall project also includes an amendment to the Bioethics Act for expanding the scope of research on gene therapies.

The third sector of IPP is the fintech industry. The government attempted to withdraw any legal measure that unnecessarily impedes the development of fintech and to design certain innovative financial services by providing a regulatory sandbox. This regulatory development includes an amendment to the Financial Information Act and the adoption of a regulation on peer-to-peer (P2P) finance. The fourth is future automobiles, which focuses on both eco-friendly and autonomous cars. The government has also established an infrastructure plan for autonomous cars, such as cooperative-intelligent transportation systems.

The remaining leading industries are smart city, smart farm, new energy, and drone. Similar to the other areas, the government plans to provide financial support and sandbox measures for developing the rest of the selected leading industries. Details about the overall investments are shown in Table 6.

\section{The Political Economy of the Innovation Policy}

\section{Trade-offs among Policy Goals and Dynamic Efficiency}

The Korean government recently provided various measures and policies to resolve issues relating to low economic growth, a high unemployment rate, and income polarization. Interestingly, the government explained its priorities: creating new jobs as a key means of solving these problems. However, it needs to recognize some intrinsic problems in its policy of incomeled growth. It is possible that there have been adverse effects from the drastic increase in the minimum wage. For example, in the first quarter of 2018, the employment rate decreased by $16.8 \%$ from the same period in 2017. Earned household income also declined by $22.6 \%$ [Statistics Korea, 2019]. In effect, the incomeled growth theory includes the indirect influence of rising consumption, thereby improving economic growth through wage increases. Nevertheless, it appears that the rapid increase in the minimum wage has generated a side effect of unemployment because small businesses are reluctant to hire employees. To solve this problem, the government has tried to promote innovation-driven growth. This means that there is a clear functional logic within the IPP, which is allegedly 
Table 6. The Investment Plan for the Eight Leading Industries (billion KRW)

\begin{tabular}{|l|l|l|l|l|}
\hline \multirow{2}{*}{} & \multirow{2}{*}{$\mathbf{2 0 1 8 ( A )}$} & \multirow{2}{*}{$\mathbf{2 0 1 9 ( B )}$} & \multicolumn{2}{|c|}{ Increase } \\
\cline { 4 - 5 } & & & \multicolumn{1}{|c|}{ (B-A) } & \multicolumn{1}{c|}{} \\
\hline Total & 2168.6 & 3520.0 & 1350.0 & 62 \\
\hline Future Automobiles & 590.7 & 760.0 & 170.0 & 29 \\
\hline Drone & 69.8 & 120.0 & 50.0 & 72 \\
\hline New Energy & 597.1 & 870.0 & 280.0 & 47 \\
\hline Bio-Health & 271.8 & 350.0 & 80.0 & 29 \\
\hline Smart Factory & 444.6 & 1030.0 & 590.0 & 133 \\
\hline Smart City & 76.7 & 130.0 & 50.0 & 65 \\
\hline Smart Farm & 114.4 & 240.0 & 130.0 & 114 \\
\hline Fintech & 36 & 100 & 60 & 167 \\
\hline Souce & \multicolumn{3}{|l}{}
\end{tabular}

Source: [Korean Government, 2018]

to resolve the current economic downturn caused by the rapid minimum wage increase.

However, there are notable conflicts among the principles of economic growth in government policies. The policies for income-led growth and a fair economy (or fair competition) may clash with that of innovationdriven growth. In particular, it is certain that the improvement of equity through increasing incomes and the enhancement of dynamic efficiency through innovation are important for modern society. The critical question is, therefore, how to appropriately balance the two objectives.

Importantly, innovation policies should be promoted with a long-term perspective, not short-term performance. Therefore, the recent project that aims to solve the unemployment problem should not be pursued based on a short-term perspective. This implies that an attempt to solve the current problem of unemployment through an innovation policy would ignore the fact that innovation policies are essentially effective over a long period of time. Therefore, there is a tradeoff among the policy goals. The important question is not whether an innovation-driven growth policy can solve the short-term problem of unemployment, but what conditions are needed for the long-term successes of the IPP.

\section{Fair Economy: The Dilemma between the Past and Future}

Some may argue that the government policy supporting a number of selected firms during the 1960s and 1970 s created the problem of economic concentration by the chaebols. This problem explains why the current government has adopted the policies of incomedriven growth and fair economy, as shown in Table 2. Regarding the fair economy policy, there is also a strong belief that a fair economy plays a pivotal role in resolving economic concentrations and societal inequality as a whole. This eventually generates the fair economy concept for the redistribution of wealth by vigorously enforcing competition law [Stiglitz, 2012].
However, implementing fair economy policies can often bring about excessive market intervention and there is the possibility of having another trade-off in policy goals between a fair economy and innovation. In particular, recent fair economy policies may hamper a series of individual investments on the market, especially those involving the development of AI. A failure, such as the hindrance of AI innovation due to stringent regulations, represents a 'government failure'.

In effect, quite a number of competition law cases against large technology companies, such as Microsoft, Intel, and Qualcomm, indicate the demonstration of a social market economy in view of fairness. The Korean competition authority has imposed notable sanctions on these companies, and Korean companies have been no exception. This trend seems to prefer fair economies over the dynamic efficiency rationale [Choi, 2010].

In order for the IPP-related industries to be developed, large-scale capital investment is needed in the emerging stage of the industrial life cycle and typically only big companies can afford this. Consequently, we need to distinguish between the rationale of regulating economic concentrations formed in the past and the rationale of fostering capital concentrations preparing for the future. The distinction between the two may appear easy to make in theory but difficult in practice, because together the two rationales are simultaneously concerned with chaebols. Therefore, in its implementation of a fair economy, the government should examine the dynamic efficiency factor [Baldwin et al., 2012; Viscusi et al., 2018].

\section{Deregulation: Regulatory Sandbox and a Competent Government}

As Schumpeter mentioned, innovation is 'a gale of creative destruction' [Schumpeter, 1942]. Creative destruction reconstructs existing social relations between individuals, businesses, capital, and labor. Regulations can be used as a tool to monitor and interrupt such reconstructions. The objective of regulation is to protect consumers and ensure safety when new technologies are introduced. On the contrary, the development of new tech businesses can be hindered when large incumbents are able to use regulatory tools to prevent new entrants on the market. Such is the case of regulatory capture when strong regulations trigger an impediment to innovation [Stigler, 1971].

Regarding the implementation of the IPP, there are discussions about reforming technology regulations. For example, certain legal regulations on IPP-related industries are broadly concerned with the following areas: remote digital healthcare (or medical treatment), a new banking system, and a new taxi system based on the sharing economy. This also concerns institutional issues, such as ensuring flexible labor markets and resolving conflicts between large manufacturers and small innovators (namely, industrial ecosystems). Excessive regulations may be used as a means 
of unnecessary monitoring and hinder technological progress. Technological innovations can be achieved with parallel regulatory reforms. In effect, the general definition of deregulation involves the issues of market entry and price, and it should indicate that any entry restrictions to innovation are removed [Decker, 2015].

The Korean government has tried to deal with technology deregulation by adopting a regulatory sandbox. The concept of a regulatory sandbox refers to a mechanism for the easing of regulations for new goods and services under certain conditions for the sake of making it possible for tests to be done before they are launched on the market [Lee, Chung, 2019]. This approach has been discussed by numerous ministries in various areas, including ICT, industry convergence, and financial regulatory sandboxes. Sandboxes are granted through inter-agency consultations, because it concerns inter-agency responsibilities. This means that regulatory reforms are not a matter of a single ministry, but that of collaboration, which is not an easy task for the government [Ministry of Economy \& Finance, 2019c]. To keep up with technological changes, the Korean government needs to have more flexibility in policymaking and competencies to meet the speed of changes. Therefore, making the government itself more competent may represent the most challenging task for regulatory reform.

\section{Concluding Remarks}

The Korean government is trying to promote growth and income distribution through the three economic policies: income-led growth, innovation-driven growth, and fair economies. Income-led growth, best exemplified by the increase of the minimum wage, intended to boost household incomes to stimulate consumption and promote production. However, it has been criticized as a cause of the declining employment rate. Therefore, it was necessary for the government to consider innovation-driven growth as an alternative solution to this problem. Recently, the government adopted a focus on innovation-led growth relating to the growth engine, while supporting its labor market reform. We can only conclude that the government uses the IPP to provide actual spill-overs of its investments into the new economies.

We believe that the government's approach to the innovation-growth solution to overcome the current economic downturn is the right direction for future economic development because the recent policy shift towards innovation could help overall economic growth. However, Korean policymakers need to understand the intrinsic problem of existing economic regulations, including the law of fair economy and areas like data protection, which hamper innovation where vigorous enforcement of the law is in place. Therefore, for the IPP to be successful, it is vital to understand the trade-offs among the policy goals and to realize its dynamic efficiency by clarifying the scope of a fair economy and technology deregulation.

This article is based on a presentation given at the Second Korea-Russia SeT Policy Workshop in Moscow in January 2019. The English translation by the authors and titles of the works in Korean is authors' own and unofficial. The authors would like to thank Dr. Changyul Lee for his research assistance. This work was supported by the Hankuk University of Foreign Studies Research Fund.

\section{References}

Aghion P., Bolton P. (1997) A Theory of Trickle-Down Growth and Development. The Review of Economic Studies, vol. 64, no 2, pp. 151-172.

Bailey M.N., Zitzewitz E., Bosworth B., Westphal L.E. (1998) Extending the East Asian Miracle: Microeconomic Evidence from Korea. Brookings Papers on Economic Activity. Microeconomics, vol. 1998, pp. 249-321.

Baldwin R., Cave M., Lodge M. (2012) Understanding Regulation: Theory, Strategy, and Practice (2nd ed.), New York: Oxford University Press.

Choi Y.S. (2010) Analysis of the Microsoft, Intel, and Qualcomm Decisions in Korea. European Competition Law Review, vol. 31, no 11, pp. $470-475$.

Choi Y.S. (2014) The Rule of Law in a Market Economy: Globalisation of Competition Law in Korea. European Business Organization Law Review, vol. 15, no 3, pp. 419-437.

Decker C. (2015) Modern Economic Regulation: An Introduction to Theory and Practice, Cambridge: Cambridge University Press.

Eichengreen B., Chung D.-K. (2004) Introduction. The Korean Economy Beyond the Crisis (eds. D.-K. Chung, B. Eichengreen), Cheltenham and Northampton: Edward Elgar, pp. 1-24.

Kim G.H. (2017) The Nature and Limits of Income-led Growth Theory. Labor Society, vol. 197, pp. 27-31 (in Korean).

Kim S.S. (2017) A Study on Policy Problem Structuring and Problem Definition: Focusing on the Frame (Discourse) of Economic Democratization. Korean Society and Public Administration, vol. 28, no 3, pp. 53-81 (in Korean).

Kim T.I. (2018) Assessments of the Income-led Growth and Future Policy Direction. Proceedings of the Autumn Conference of 2018 of the Korean Association for Policy Studies, pp. 257-286 (in Korean).

Kim W. (2019) A Review on the Fourth Industrial Revolution: Income of the Old Age from Financial Technology. ChosunBiz, 19.05.2019. Available at: http://biz.chosun.com/site/data/html_dir/2019/05/17/2019051701120.html, accessed 22.05.2019 (in Korean).

Korean Government (2018) Innovative Platform: The Policy Direction of Strategic Investment for Innovation-Driven Growth (published online 13.08.2018). Available at: http://www.moef.go.kr/nw/nes/detailNesDtaView.do?searchBbsId1=\&searchNttId1=MOSF_000000 $000018581 \&$ menuNo=4010100, accessed 18.05.2019 (in Korean). 
Korean Government (2019) The Governmental Policy on the Eight Leading Industries (published online 20.02.2019). Available at: http://www.moef.go.kr/nw/nes/detailNesDtaView.do?searchBbsId1=\&searchNttId1=MOSF_000000000026977\&menuNo=4010100, accessed 19.05.2019 (in Korean).

Lee J.-H., Chung H.-Y. (2019) Regulatory Sandbox, Korea's New Regulation Paradigm, Seoul: KISTEP (in Korean).

Lee S.M. (2018) The Effects of Wage-Led Growth Policy on Economic Revival, Price and Employment. Koreanische Zeitschrift fur Wirtschaftswissenschaften, vol. 36, no 4, pp. 87-111 (in Korean).

Ministry of Economy \& Finance (2018) 5th Ministerial Meeting on 'Growth through Innovation' (published online 14.08.2018). Available at: http://english.moef.go.kr/ec/selectTbEconomicDtl.do?boardCd=E0001\&seq=4533\&boardCdKey=N, accessed 31.05.2019.

Ministry of Economy \& Finance (2019a) 1st Ministerial Meeting to Promote Innovation in Industries (published online 16.01.2019). Available at: http://english.moef.go.kr/ec/selectTbEconomicDtl.do?boardCd=E0001\&seq=4615\&boardCdKey=N, accessed 31.05.2019.

Ministry of Economy \& Finance (2019b) Measures to Boost Ventures (published online 12.03.2019). Available at: http://english.moef. go.kr/ec/selectTbEconomicDtl.do?boardCd=E0001\&seq=4640\&boardCdKey=N, accessed 31.05.2019.

Ministry of Economy \& Finance (2019c) 13th Ministerial Meeting on Boosting the Economy (published online 17.04.2019). Available at: http://english.moef.go.kr/ec/selectTbEconomicDtl.do?boardCd=E0001\&seq=4662\&boardCdKey=N, accessed 31.05.2019.

MSITC (2018) The Innovation Growth Engine. Leading Preparations for the Fourth Industrial Revolution, Seoul: Ministry of Science and ICT. Available at: https://iac.nia.or.kr/board_files/96/download, accessed 11.06.2019.

OECD (2017) Economic Outlook No. 101 - June 2017, Paris: OECD.

Park J. (2019) Labor Productivity and Wage in Korean Economy. Korean Economic Forum, vol. 12, no 1, pp. 81-112 (in Korean).

Presidential Committee (2019) Income-led Growth (Note by the Presidential Special Committee for Income-led Growth in Korea). Available at http://ilg.go.kr/html/sub2_1.do, accessed 30.05.2019 (in Korean).

Posner R.A. (2001) Antitrust in the New Economy. Antitrust Law Journal, vol. 68, no 3, pp. 925-943.

Schumpeter J.A. (1942) Capitalism, Socialism, and Democracy, New York: HarperPerennial.

Statistics Korea (2018) Household Income Trends in the Third Quarter of 2018. Available at http://kostat.go.kr/portal/eng/pressReleases/6/1/ index.board, accessed 30.05.2019.

Statistics Korea (2019) Economically Active Population Survey (published online 15.05.2019). Available at http://kostat.go.kr/portal/eng/ pressReleases/5/1/index.board, accessed 30.05.2019.

Stigler G. (1971) The Economic Theory of Regulation. Bell Journal of Economics, vol. 11, pp. 3-21.

Stiglitz J.E. (2012) The Price of Inequality: How Today's Divided Society Endangers Our Future, New York: W.W. Norton \& Co.

Ungson C.R., Steers R.M., Park S.-H. (1997) Korean Enterprise: The Quest for Globalization, Cambridge, MA: Harvard Business School Press.

Viscusi W.K., Harrington Jr. J.E., Sappington D.E.M. (2018) Economics of Regulation and Antitrust (5th ed.), Cambridge, MA: MIT Press. 